\title{
FORMATION AND PROPERTIES OF CARBON IN POROUS SPACE OF SILICA-ALUMINA CERAMICS
}

Marina Vlasova $^{1 *}$, Catalina BustosRivera-Bahena ${ }^{1}$, Gloria Dominguez-Patino², Mykola Kakazey ${ }^{1}$, Rene Guardian Tapia ${ }^{1}$

${ }^{1}$ Centro de Investigaciones en Ingeniería y Ciencias Aplicadas, Universidad Autónoma del Estado de Morelos UAEM-CIICAp, Cuernavaca, Estado Morelos, México.

${ }^{2}$ Facultad de Ciencias Químicas e Ingeniería, Universidad Autónoma del Estado de Morelos FCQelUAEM, Cuernavaca, Estado Morelos, México.

E-mail:vlasovamarina@inbox.ru

\section{ABSTRACT}

By using of XRD, IR, SEM methods and microanalysis, it was investigated the process of carbon formation during thermo destruction of sucrose inside pores of silica-alumina ceramics in conditions of oxygen deficient. It was found that for carbon formation inside pores, temperature treatment of sucrose must be $600^{\circ} \mathrm{C}$ and time of heating $15 \mathrm{~min}$. At such regime of carbonization, carbon material is produced in the form of islets on the surface of pores and in the form of spherical particles of different sizes. Carbon particles present a set of aggregates from chaotic graphene clusters. On surface of carbon particles is formed grapheme oxide. Obtained results show that the carbonized ceramics adsorbs in a good degree the dyes from water solution.

\section{Indexing terms/Keywords}

Porous ceramics, sucrose, carbonization, adsorption of dyes.

\section{Academic Discipline And Sub-Disciplines}

Environmental Chemistry

\section{SUBJECT CLASSIFICATION}

Carbonized ceramics for adsorption

TYPE (METHOD/APPROACH)

Experimental

\section{Council for Innovative Research}

Peer Review Research Publishing System

\section{Journal: Journal of Advances in Chemistry}

Vol 11, No. 7

editorjaconline@gmail.com, www.cirjac.com 


\section{INTRODUCTION}

Porous ceramics with different pore sizes may be of interest not only as a structural material in the form of porous bricks [1, 2], but also for the filtration of water from solid residues and microorganisms [3-8]. Recently, interest is the use of porous ceramics with a modified surface of pores, in particular with carbon. It was found that the porous structure of sandwich type ceramics - carbon layer, obtained by carbonization polymeric precursors can be used as gas separation membranes, as adsorbents or supports for catalysis [9-13].

There is a huge variety of technological methods and techniques to produce a highly porous ceramics [14-24]. The most commonly used method is the burnout of additives and a decomposition of chemical compounds are used [2329]. The main agents of pores formation are allocation of gases and vapors $\left(\mathrm{CO}_{2}, \mathrm{CO}, \mathrm{H}_{2} \mathrm{O}\right)$. For the synthesis of ceramic with a large pores size (up to $\sim 8 \mathrm{~mm}$ ) it was used the method of impregnation of polyurethane sponge with clay slurry followed by sintering of the composite [23, 24], and introduction of different content of spherical particles of polystyrene into clay slurry (suspension) [19, 30].

The aim of this work is a low-temperature synthesis of ceramics with different size of pores on base of mixture bentonite-glass, obtained by the method of burnout of additives, and creation of carbon layer on surface of pores. It is supposed that such material must have adsorptive properties for removal of dyes from industrial waste water.

\section{METHODS}

The basic components used for sintering of ceramics, were bentonite and grinded glass. For reducing the temperature and time sintering, it was choosen cullet with low temperature of melting [31]. Composition of used components is present in Table 1. For obtaining a porous ceramics with big size of pores, it was selected the method of burnout agents, namely, a spherical particles of polystyrene in diameter $\sim 5 \mathrm{~mm}$. By mixing $50 \mathrm{wt} \%$ bentonite +50 wt. $\%$ glass with particle size $\sim 90 \mu \mathrm{m}$ was prepared slurry in which were introduced spherical particles of polystyrene. The content of particles of polystyrene was such as to provide the maximum open porosity of ceramic material. Sintering of semi-products was realized at 600,700 and $900{ }^{\circ} \mathrm{C}$ during $60 \mathrm{~min}$. As a source of a carbon, a saturated sucrose solution was used. Samples of ceramics were immersed in a sucrose solution and heated on a hot plate until the evaporation of the water and the caramelization of sucrose starts. The resulting samples were placed in aluminum foil, and then were calcined in a furnace at $600^{\circ} \mathrm{C}, 700^{\circ} \mathrm{C}$, and $900^{\circ} \mathrm{C}$ during $15 \mathrm{~min}$.

Table 1. The chemical composition of the used components

\begin{tabular}{|c|c|c|c|c|c|c|c|c|c|}
\hline \multirow[t]{2}{*}{ Component } & \multicolumn{5}{|c|}{ Composition, wt. \% } & & & & \\
\hline & $\mathrm{SiO}_{2}$ & $\mathrm{Al}_{2} \mathrm{O}_{3}$ & $\mathrm{Fe}_{2} \mathrm{O}_{3}$ & $\mathrm{Na}_{2} \mathrm{O}$ & $\mathrm{CaO}$ & $\mathrm{MgO}$ & $\mathrm{TiO}_{2}$ & $\mathrm{~K}_{2} \mathrm{O}$ & $\Sigma_{\text {rest }}$ \\
\hline Bentonite & 64.0 & 21.0 & 2.8 & 2.7 & 1.0 & 3.2 & not & 0.4 & 4.9 \\
\hline Glass & 72.03 & 1.989 & not & 13.964 & 7.006 & 4.005 & not & 1.001 & 0.005 \\
\hline Ceramic (50 wt. \% & 70.2 & 7.9 & 1.7 & 1.0 & 6.0 & 7.0 & 0.1 & 01 & 0.2 \\
\hline glass) & & & & & & & & & \\
\hline
\end{tabular}

An X-ray analysis of the specimens was performed using a Siemens D-500 diffractometer in Cu $K_{\alpha}$ radiation. A SEM study and micro chemical analysis was carried out with a LEO 1450 VP microscope. IR spectra were obtained on Brucker Vector 22 FT spectrometer. To obtain the UV-visible spectra, a Perkin Elmer Lambda 25 spectrometer was used.

For the adsorption measurements of carbonized ceramics, the obtained specimens were placed in aqueous solutions of methylene blue (MB) and drimaren red (DR). For determination of adsorptive properties of carbonized ceramics, experiments were performed in which concentration of dyes in water, content of carbonized ceramics, or exposure time was changed. Concentration of $\mathrm{MB}$ and $\mathrm{DR}$ in the solutions was evaluated from the calibration curve $I=f(c)$, where $I$ is intensity of UV-visible band $660 \mathrm{~nm}$ for MB and $508 \mathrm{~nm}$ for DR, $c$ is concentration of MB and DR in prepared solution. Kinetic parameters were estimated as given in [32].

\section{RESULTS AND DISCUSSION}

\subsection{Initial ceramics}

In the sintered ceramics the pores of different size are present (Fig. 1 a - c). Surface of large pores and walls between them are permeated by smaller pores. Substantial part of adjacent pores form channels that have output to the sample surface. The appearance of pores with $\mathrm{d} \sim 5 \mathrm{~mm}$ is caused with burnout of polystyrene spherical particles, which ends at $800^{\circ} \mathrm{C}$ (Fig. 2). The formation of pores of a smaller size are the result of gases and vapors allocation. The elemental composition of the ceramics is consistent with data Table 1 (see Fig. $1 \mathrm{c}$ ). 

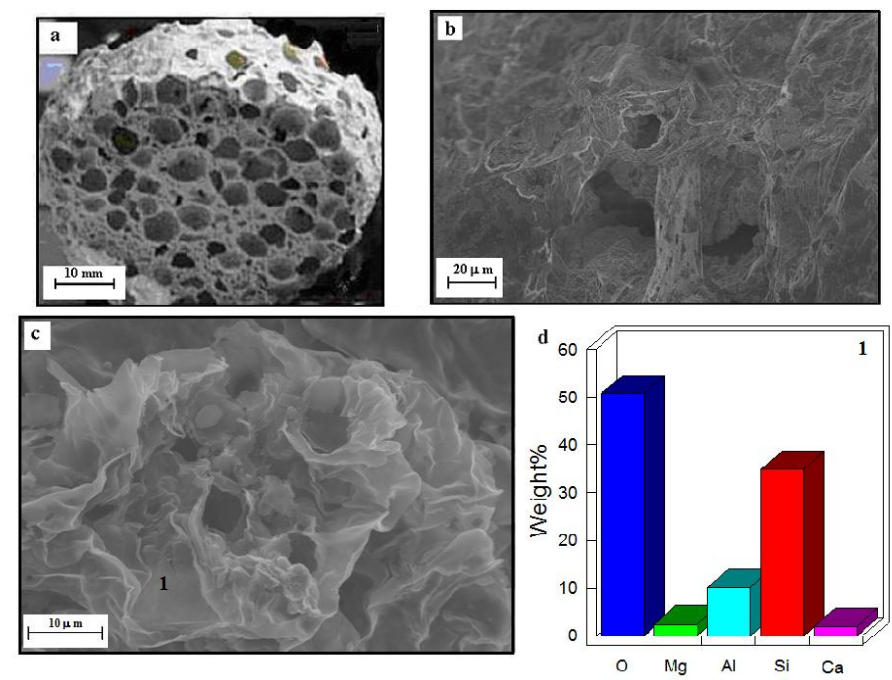

Fig. 1: Micro photo of obtained ceramics at different magnification (a-c) and content of elements in ceramics (d). $\mathrm{T}_{\text {sint. }}=900^{\circ} \mathrm{C}, \mathrm{t}_{\text {sint. }}=60 \mathrm{~min}$.

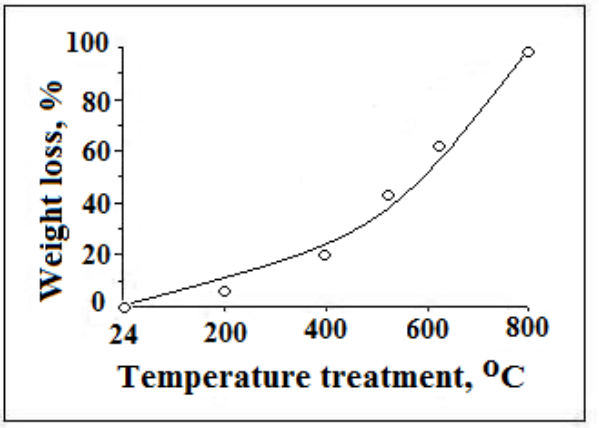

Fig. 2: Weight loss of polysterene spheres during temperature treatment. $t_{\text {tr. }}=15$ min.

X-ray data indicate that phase composition of porous specimens obtained in region $\mathrm{T}_{\text {sint. }}=(600-900){ }^{\circ} \mathrm{C}(\mathrm{Fig} .3 \mathrm{a})$ is a typical for mixture montmorillonite-glass treated in this temperature range [23, 24]. The crystalline phases are presented with cristobalite, quartz and feldspar. In the low-temperature region of sintering montmorillonite can still be found. However, at $\mathrm{T}_{\text {sint. }}>700{ }^{\circ} \mathrm{C}$ a complete disintegration of the clay mineral occurs the restructuring in the system cristobalite - quartz- feldspar. Overlay of narrow diffraction lines on the halo indicates that together with crystalline phases in the ceramics exists amorphous (glassy) phase [23, 24].

The IR-spectra of ceramics obtained at $\mathrm{T}_{\text {sint }} \geq 600^{\circ} \mathrm{C}$ (Fig. $4 \mathrm{a}$, b, curves 1, 1' and Table 2) represent superposition of spectra of silicate glasses, in which quartz, cristobalite, and feldspar present [31, 33,34].

Table 2. IR-bands of adsorption in investigate samples obtained from mixture $50 \mathrm{wt} \%$ bentonite $+\mathbf{5 0}$ wt. $\%$

\begin{tabular}{|c|c|c|c|c|}
\hline Samples & \multicolumn{4}{|c|}{$\mathrm{v}, \mathrm{cm}^{-1}$} \\
\hline $\begin{array}{l}\text { Bentonite } \\
\text { (montmorillonite) }\end{array}$ & $\begin{array}{l}3705.8 \\
3426.5 \mathrm{~s} . \mathrm{m} .\end{array}$ & $1639.8 \mathrm{~m}$. & $\begin{array}{l}1088.24915 .6 w .841 .5 w .794 .6 w . \\
1036.7 s .\end{array}$ & $\begin{array}{l}623.3 \\
519.9 \\
467.5 \mathrm{~m} .\end{array}$ \\
\hline Initial mixture & $\begin{array}{l}3627 \mathrm{~m} . w d . \\
3442 \text { m. wd. }\end{array}$ & $1642 \mathrm{~m}$. & $\begin{array}{l}\text { 1084sh. } \\
\text { 1030s.wd. } \\
\text { 915sh. }\end{array}$ & $\begin{array}{l}620 \\
518 \\
464 s .\end{array}$ \\
\hline $\mathrm{T}_{\mathrm{s}}=600{ }^{\circ} \mathrm{C}$ & $\begin{array}{l}3612 w . \\
3442 w .\end{array}$ & 1626w. & $\begin{array}{c}\left.\begin{array}{c}1095 \\
1045\end{array}\right\} \mathrm{s} . \\
1030\end{array}$ & $\begin{array}{l}\text { 599m. } \\
475 \mathrm{~s} .\end{array}$ \\
\hline $\mathrm{T}_{\mathrm{s}}=700{ }^{\circ} \mathrm{C}$ & & & $\left.\begin{array}{c}1096 \\
1030\end{array}\right\}$ s.wd. 907m. 795m. & $\begin{array}{l}\text { 480s. } \\
468 .\end{array}$ \\
\hline
\end{tabular}




\begin{tabular}{|c|c|c|c|}
\hline $\mathrm{T}_{\mathrm{s}}=800^{\circ} \mathrm{C}$ & $\left.\begin{array}{c}1030 \\
1095\end{array}\right\}^{\text {s.wd. }}$ & 790w. $\quad 624 w$. & $\begin{array}{l}\text { 568sh. } \\
\text { 468m.wd. }\end{array}$ \\
\hline $\mathrm{T}_{\mathrm{s}}=900^{\circ} \mathrm{C}$ & $\begin{array}{l}\text { 1030sh. } \\
\text { 1098s.wd. }\end{array}$ & 800w.wd. 624w. & 470m.wd. \\
\hline $\mathrm{SiO}_{2}$ (cristobalite) & $\begin{array}{l}1119 s . \\
1172 \text { sh. }\end{array}$ & 800w. $\quad 619 w$. & $496 \mathrm{~m}$. \\
\hline $\mathrm{SiO}_{2}$ (quartz) & $\begin{array}{l}\text { 1084s. } \\
\text { 1150sh. }\end{array}$ & $\left.\begin{array}{l}798 \\
780\end{array}\right\} \mathrm{m} . \quad 697 w$. & $\begin{array}{l}\text { 520w. } \\
466 s .\end{array}$ \\
\hline $\begin{array}{l}\text { Glass } \\
\mathrm{Na}_{2} \mathrm{O}-\mathrm{Al}_{2} \mathrm{O}_{3-} \\
\mathrm{SiO}_{2}\end{array}$ & $\begin{array}{l}\text { 1160s.wd. } \\
\text { 980sh. }\end{array}$ & $800 w$. & $\begin{array}{l}580 w . \\
480 s .\end{array}$ \\
\hline
\end{tabular}

Note: $\mathrm{s}$. is strong band, $\mathrm{m}$. is middle, w. is weak, wd. is wide, sh. is shoulder. The greasy font marks the basic band, on which the bands given in column settle down.

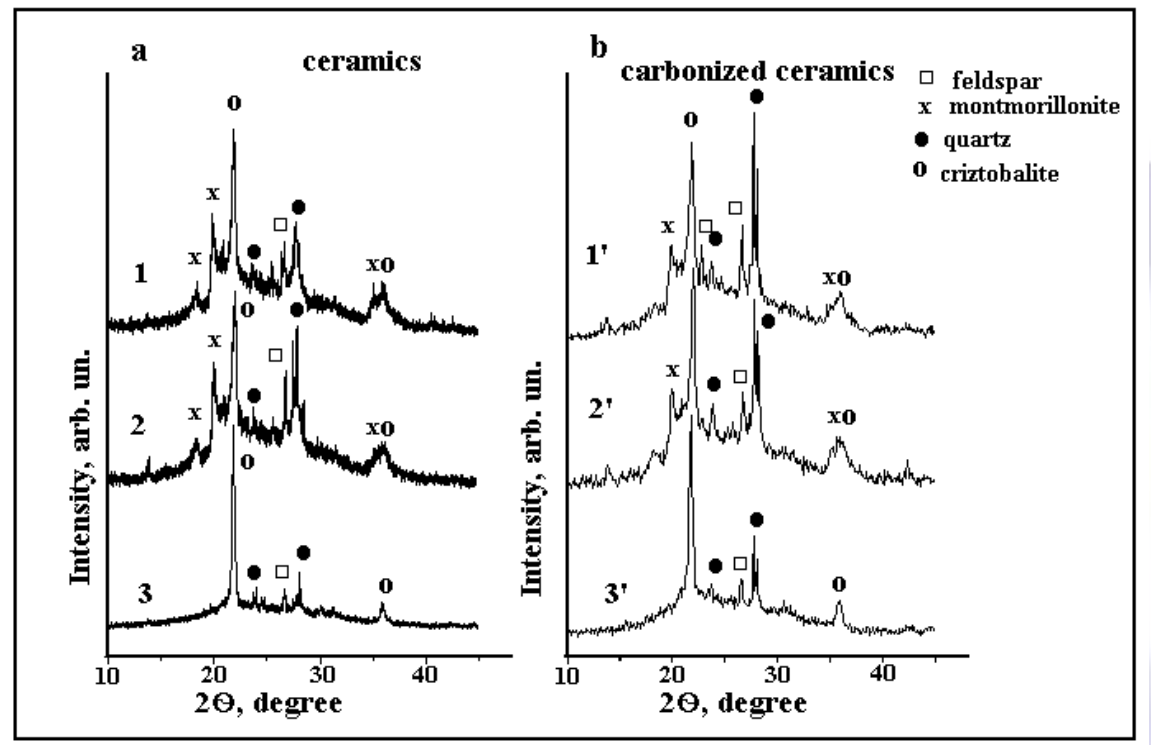

Fig. 3: Diffraction patterns of ceramic specimens obtained at different temperatures (a) and carbonized ceramics (b).

For a: (1) after $\mathrm{T}_{\text {sint. }}=600^{\circ} \mathrm{C}$, (2) $700^{\circ} \mathrm{C}$, (3) $900{ }^{\circ} \mathrm{C}$. $\mathrm{t}_{\text {sint. }}=60 \mathrm{~min}$.

For b: (1') specimens after $\mathrm{T}_{\text {sint. }}=600^{\circ} \mathrm{C}$ and $\mathrm{T}_{\text {carbon. }}=600^{\circ} \mathrm{C},\left(2^{\prime}\right) \mathrm{T}_{\text {sint. }}=600^{\circ} \mathrm{C}$ and $\mathrm{T}_{\text {carbon. }}=700^{\circ} \mathrm{C},\left(3^{\prime}\right) \mathrm{T}_{\text {sint. }}=$ $600^{\circ} \mathrm{C}$ and $\mathrm{T}_{\text {carbon. }}=900^{\circ} \mathrm{C}$. $\mathrm{t}_{\text {carbon. }}=15 \mathrm{~min}$. 


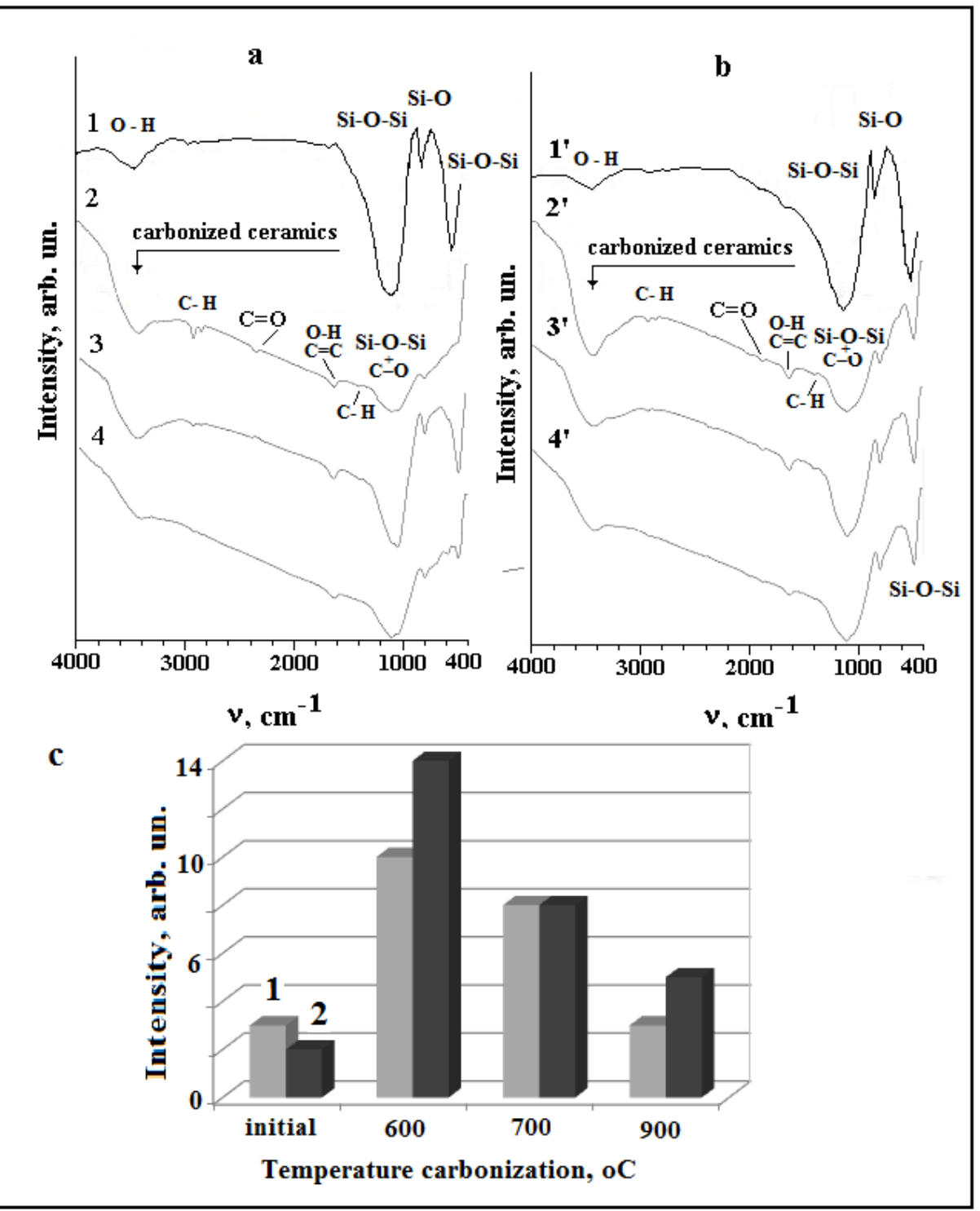

Fig. 4: IR spectra specimens obtained from mixture 50 wt. $\%$ glass -50 wt. $\%$ bentonite before and after carbonization (a, b) and change IR-bands intensity (c).

For (a): (1) mixtures glass - bentonite after $\mathrm{T}_{\text {sint }}=600^{\circ} \mathrm{C}$ and $t_{\text {sint. }}=60 \mathrm{~min}$.; (2) mixture 1 after $\mathrm{T}_{\text {sint }}=600{ }^{\circ} \mathrm{C}$ and $\mathrm{T}_{\text {carbon. }}=600^{\circ} \mathrm{C}$, (3) mixture 1 after $\mathrm{T}_{\text {sint }}=600^{\circ} \mathrm{C}$ and $\mathrm{T}_{\text {carbon. }}=700^{\circ} \mathrm{C}$, (4) mixture 1 after $\mathrm{T}_{\text {sint }}=600^{\circ} \mathrm{C}$ and $\mathrm{T}_{\text {carbon. }}$. $=900^{\circ} \mathrm{C} . \mathrm{t}_{\text {carbon. }}=15 \mathrm{~min}$.

For (b): (1') mixture after $\mathrm{T}_{\text {sint }}=(800-900)^{\circ} \mathrm{C}$, and $\mathrm{t}_{\text {sint. }}=60 \mathrm{~min}$.; (2') mixture $1^{\prime}$ after $\mathrm{T}_{\text {sint }}=900{ }^{\circ} \mathrm{C}$ and $\mathrm{T}_{\text {carbon. }}=$ $600^{\circ} \mathrm{C},\left(3^{\prime}\right)$ mixture $1^{\prime}$ after $T_{\text {sint }}=900^{\circ} \mathrm{C}$ and $T_{\text {carbon. }}=700^{\circ} \mathrm{C},(4)$ mixture $1^{\prime}$ after $T_{\text {sint }}=900{ }^{\circ} \mathrm{C}$ and $T_{\text {carbon. }}=900$ ${ }^{\circ} \mathrm{C} . \mathrm{t}_{\text {carbon. }}=15 \mathrm{~min}$.

For (c): $(1,2)$ band of $\mathrm{O}-\mathrm{H}$ bonds at $\mathrm{v} \sim 3430 \mathrm{~cm}^{-1}$. (1) for specimen with $\mathrm{T}_{\text {sint }}=600{ }^{\circ} \mathrm{C}$, (2) for specimen with $\mathrm{T}_{\text {sint }}=900^{\circ} \mathrm{C}$. $\mathrm{t}_{\text {carbon. }}=15 \mathrm{~min}$.

\subsection{Carbonized sucrose}

Temperature treatment of "pure" sucrose in region $(600-900){ }^{\circ} \mathrm{C}$ is accompanied by the formation of the wide superposition diffraction lines at small angles, and also at $2 \theta \sim 22^{\circ}$ (Fig. 5 a). It indicates the development of the process of carbonization and the formation of sugar coke [35]. The presence of lines with a maximum at $2 \theta \sim 10^{\circ}$ and $22^{\circ}$ is characteristically for amorphous component of material, and the appearance of a narrow peak at $2 \theta \sim 25^{\circ}$ is due to the presence of a minor amount of more structured forms of carbon (see Fig. 5 a). In the number of investigations [36-42] it was established that the broad lines at $2 \theta \sim(10-26)^{\circ}$ are related to graphene and grapheme oxide. With increasing of $\mathrm{T}_{\text {sint. }}$ up to $700{ }^{\circ} \mathrm{C}$ notes the restructuring in carbon material: intensity of wide lines increases, narrow (002) line of graphite disappears (see Fig. $5 \mathrm{a}, \mathrm{b}$ ). And at $\mathrm{T}_{\text {sint. }}=900{ }^{\circ} \mathrm{C}$ partial burnout of carbon due to presence oxygen in furnace takes place (see Fig. 5 b). 

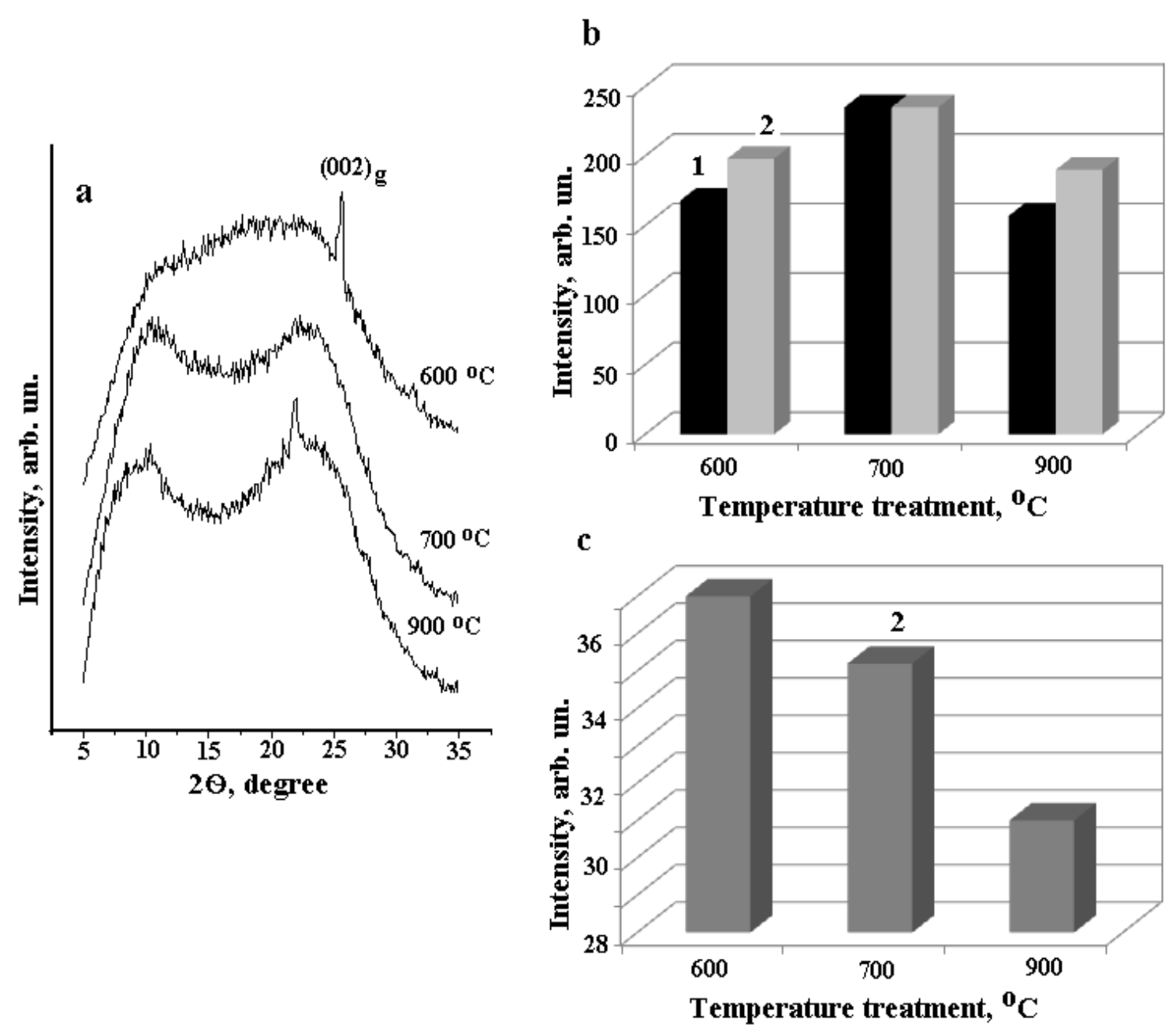

Fig. 5: X-ray diffraction patterns of specimens obtained at different temperatures of sucrose carbonization (a) and change of halo intensities in carbonized sucrose (b), and carbonized ceramics (c).

For a: (1) after $\mathrm{T}_{\text {carb. }}=600^{\circ} \mathrm{C}$, (2) $700{ }^{\circ} \mathrm{C}$, (3) $900{ }^{\circ} \mathrm{C}$. $t_{\text {sint. }}=60 \mathrm{~min}$. Narrow pick at $2 \theta \sim 25^{\circ}$ corresponds to graphite.

For $b$ and $c$ : (1) corresponds to halo intensity at $2 \theta \sim 10^{\circ}$, and (2) corresponds to halo intensity at $2 \theta \sim 22^{\circ}$. $t_{\text {carbon. }}=15 \mathrm{~min}$.

\subsection{Carbonized ceramics}

Diffraction patterns, which were received for ceramics after $\mathrm{T}_{\text {sint. }}=600{ }^{\circ} \mathrm{C}$ and then carbonized at different temperatures are not different fundamentally (see Fig. $3 \mathrm{a}, \mathrm{b}$ ). It proved impossible assess the contribution of amorphous carbon peaks at $2 \theta \sim 10^{\circ}$ and $2 \theta \sim(15-30)^{\circ}$ (see Fig. $3 \mathrm{a}, \mathrm{b}$ ). This means that the content of amorphous carbon in specimens is significantly less than in carbonized sucrose. A rough estimate the intensity of the halo in region $2 \theta \sim 25^{\circ}$ showed that in carbonized ceramics it decreases faster than for pure sucrose (see Fig. $5 \mathrm{~b}, \mathrm{c}$ ). This may be due the rapid elimination (burning) carbon layer from the surface of pores. It should be noted that the main contribution into formation of a halo in the region $25-30^{\circ}$ makes glass phase, which is present in ceramics [23, 24]. But at the selected mode carbonization its amount cannot vary.

According to IR spectroscopy data, as a result of temperature treatment at $600{ }^{\circ} \mathrm{C}$ ceramics with deposited on its surface the sucrose, a significant decrease in the intensity of the absorption bands of a silicate system ( $\mathrm{Si}-\mathrm{O}-\mathrm{Si}$, Si-O bonds) has been observed and the formation of a wide band on which the present band of $\mathrm{O}-\mathrm{H}$ bonds and weak bands of $\mathrm{C}=\mathrm{C}, \mathrm{C}-\mathrm{H}, \mathrm{C}-\mathrm{O}$, bonds (see Fig. $4 \mathrm{a}, \mathrm{b}$, spectra of 2, 2 '). Such transformation of the IR spectrum indicates on deposition of carbon (grapheme) on ceramic surface and formation little amount of grapheme oxide [41-44]. With increasing $\mathrm{T}_{\text {carbon. }}$ to $700{ }^{\circ} \mathrm{C}$ again increases the intensity of the absorption bands of Si-O-S and Si-O bonds, and weakened absorption band of $\mathrm{O}-\mathrm{H}, \mathrm{C}=\mathrm{C}, \mathrm{C}-\mathrm{H}, \mathrm{C}-\mathrm{O}$ bonds (see Fig. $4 \mathrm{a}, \mathrm{b}$, spectra 3, 3'). Subsequent changes in the spectra after $\mathrm{T}_{\text {carbon. }}=900{ }^{\circ} \mathrm{C}$ (see Fig. $4 \mathrm{a}, \mathrm{b}$, spectra 4,4 ) are caused by processes of complete burnout of the carbon layer and interaction of components in ceramic material, which is accompanied by the formation of a new type glass [24]. 
According to SEM and microanalysis (Fig. 6 and Fig. 7 a, b) within the pores of carbonized ceramics are two types of carbon formation. One of them is in the form of spherical particles of different size (with maximum diameter $10 \mu \mathrm{m}$ ). Note that on the surface of spheroids registers oxygen. The second type is nano-particles of carbon covering the surface of the pore (see Fig. 6 b, c, Fig. 7 b, and Fig. 8 a, b, b', b"). From Fig. 7 c and Fig. 8 b, b', b" it can see the uneven distribution of carbon. This distribution has "island" character. According to a rough estimate (see Fig. $7 \mathrm{c}$ ) the maximal thickness of the coating with carbon is no more than about $1 \mu \mathrm{m}$. On the surface of these clusters oxygen is also present. Figs. 8 b, b', b" show that the spherical particles and aggregates of various sizes in reality consist from particles of less size. According to modern concepts $[45,46]$ the formation of solid carbon phase begins with the formation of planar aromatic molecules (graphene-nuclei), and on their basis the formation of clusters takes place. Chaotic "coalescence" of graphene clusters, occurring in the gas phase, leads to the formation of spherical particles of amorphous soot (see Fig. 8 b"'). These stages can be seen in Fig. 8 b".

The obtained results showed that carbonization of sucrose in porous ceramics in conditions of oxygen deficit are accompanied with formation of different type of particles on the base of disordered graphene packages. This means that carbonized ceramics must have adsorptive properties.

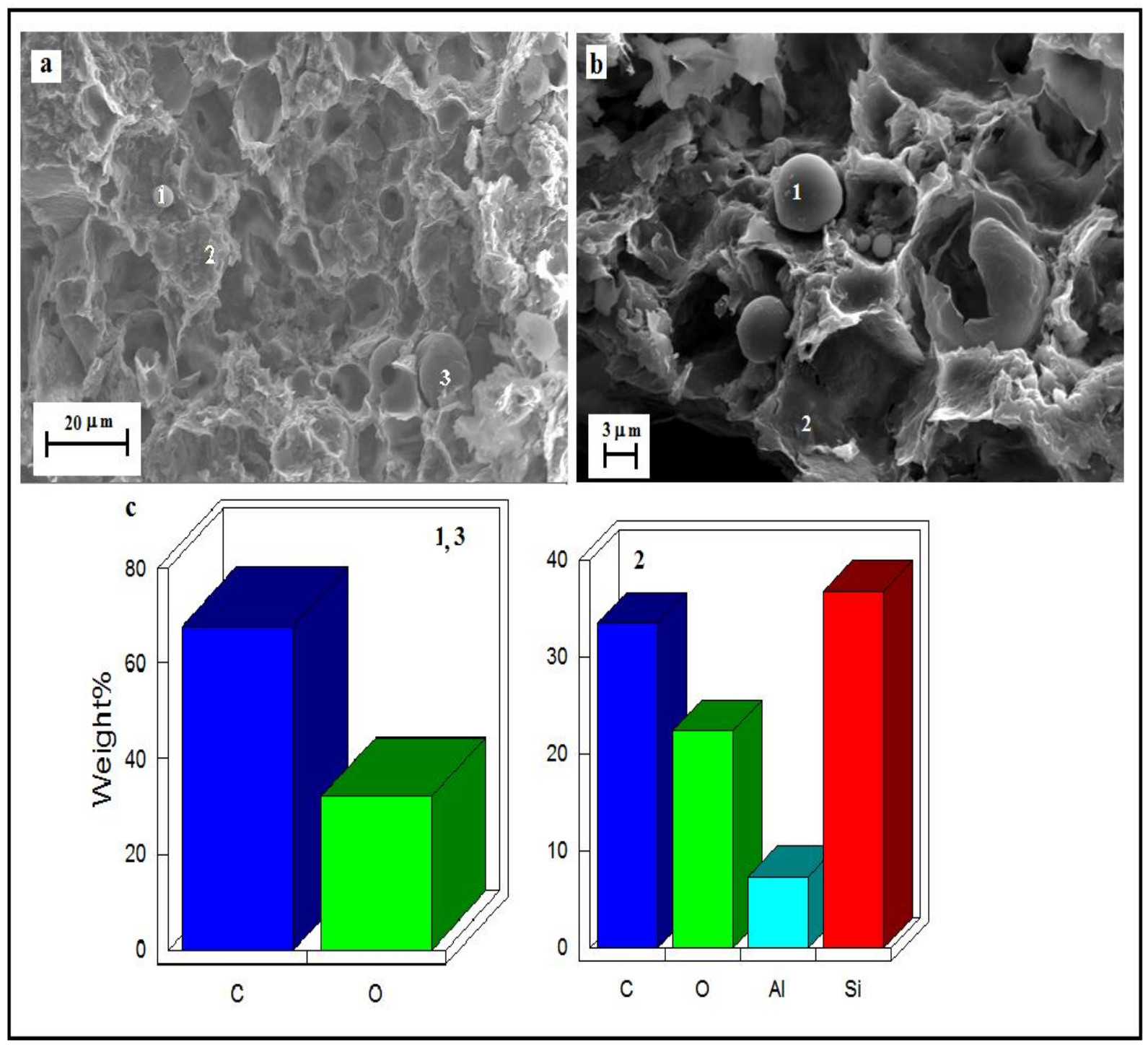

Fig. 6: SEM micrographs the surface area of carbonized porous ceramics (a) and local microanalysis (b) at the locations specified in Fig. $6 \mathrm{a}$, b. $\mathrm{T}_{\text {sint. }}=600^{\circ} \mathrm{C}$, $\mathrm{t}_{\text {sint. }}=60 \mathrm{~min}$., $\mathrm{t}_{\text {carbon. }}=15 \mathrm{~min}$. 


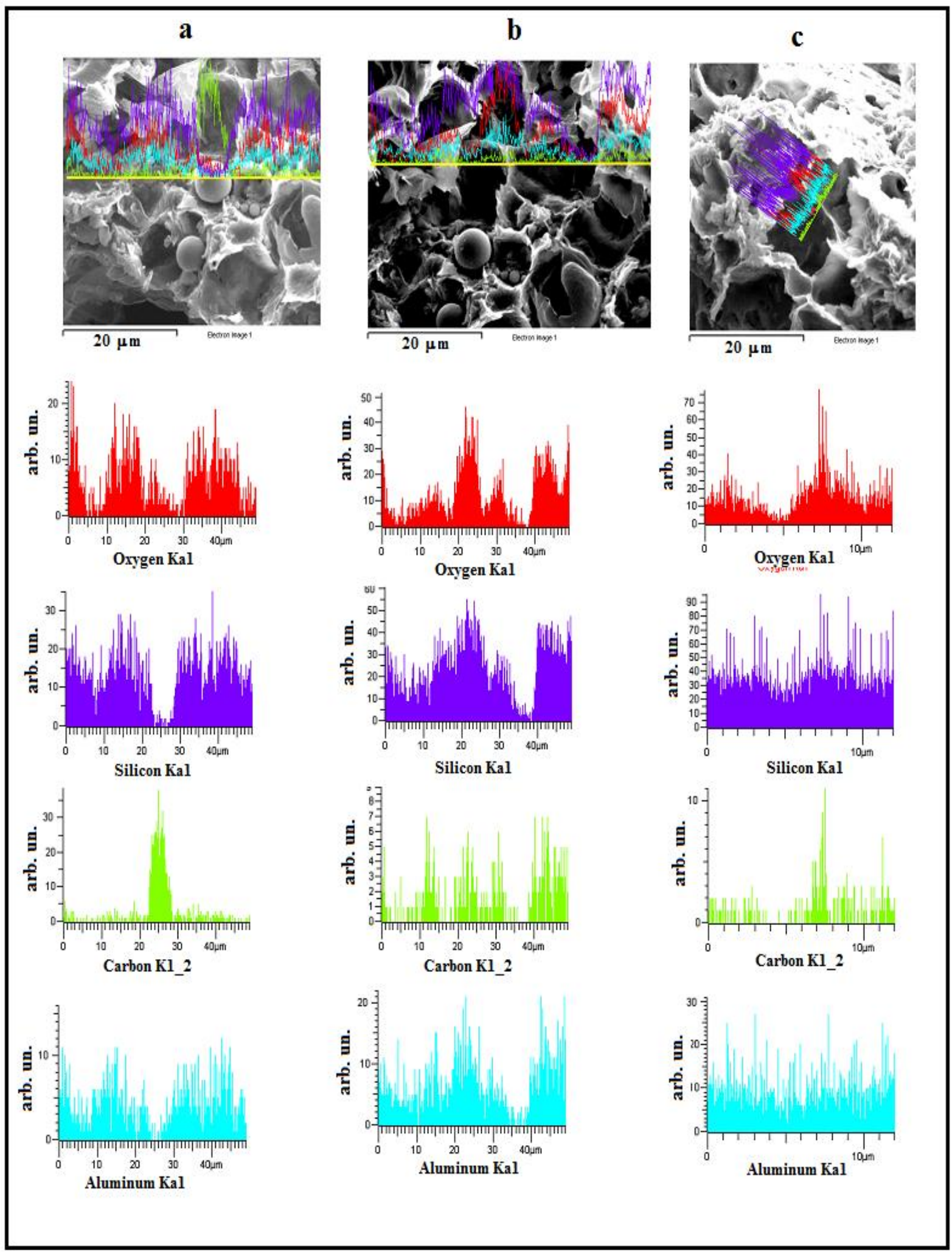

Fig. 7: The distribution of elements in the analyzed regions of carbonized porous ceramics. $\mathrm{T}_{\text {sint. }}=600{ }^{\circ} \mathrm{C}$, $t_{\text {sint. }}=60$ min., $t_{\text {carbon. }}=15 \mathrm{~min}$. 


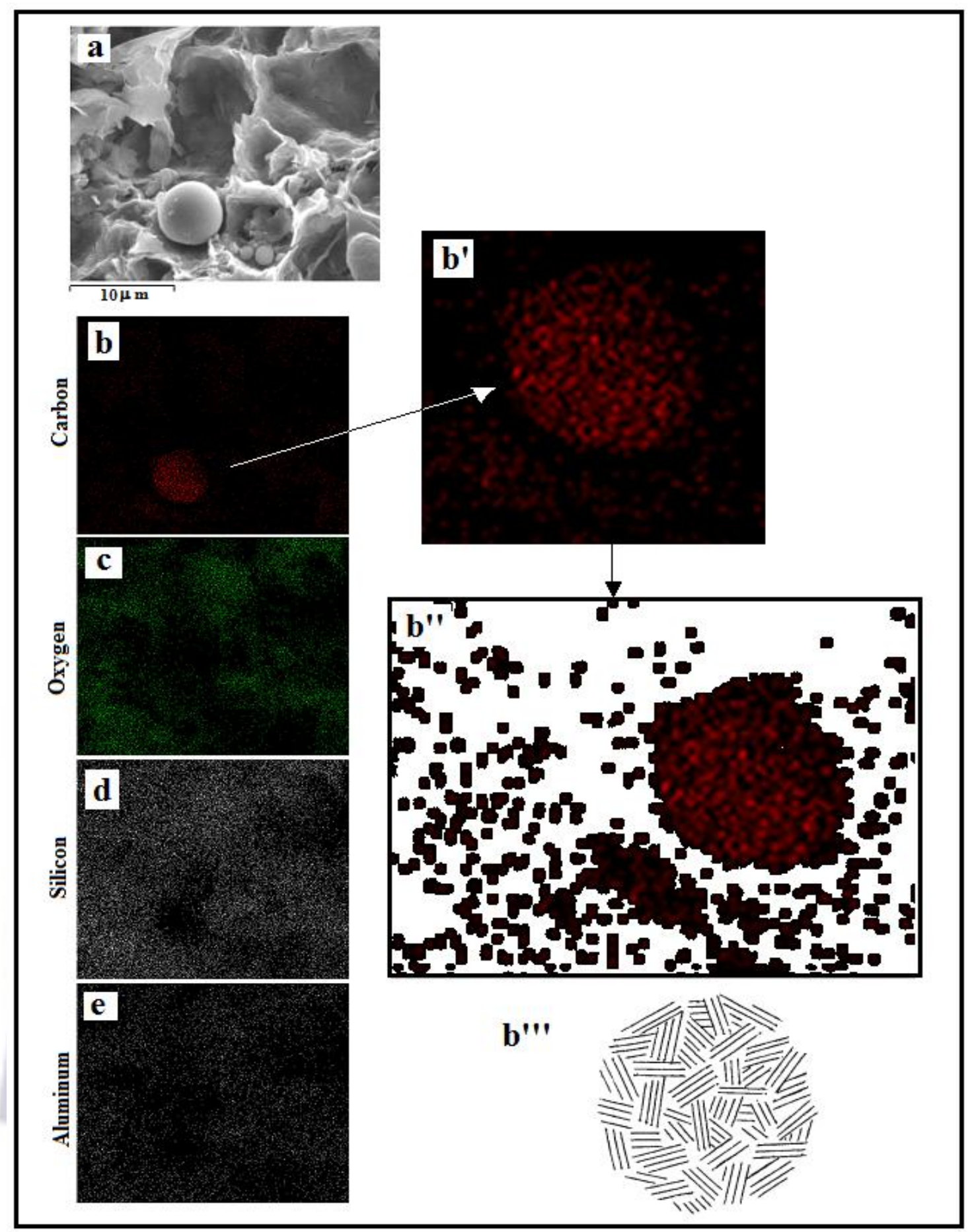

Fig. 8: The distribution of elements in the analyzed regions (a) of ceramics $\left(T_{\text {sint. }}=600{ }^{\circ} \mathrm{C}, t_{\text {sint. }}=60 \mathrm{~min}\right.$., $t_{\text {carbon. }} 15$ min). Localization of carbon: b), b'), b'); c) oxygen; d) silicon; e) aluminum. On b'”) submit the model of soot spherical particle $[45,46]$.

\subsection{Adsorptive properties of carbonized ceramics}

The presence in the pore space of ceramics graphene clusters in the form of aggregates of different size and spherical particles should initiate the adsorption of the dye from the aqueous solution. Investigations have shown that concentration of dyes in solution depends of time exposition of carbonized ceramics in solution of MB and RD (Fig 9 , a, a'), concentration dyes in solution (Fig 9 b, b') and weight of carbonized ceramics in solutions. (Fig. 9 c, c'). MB is adsorbed better than RD. All results show that the carbonized ceramics adsorbs in a good degree the dyes from water solution. 

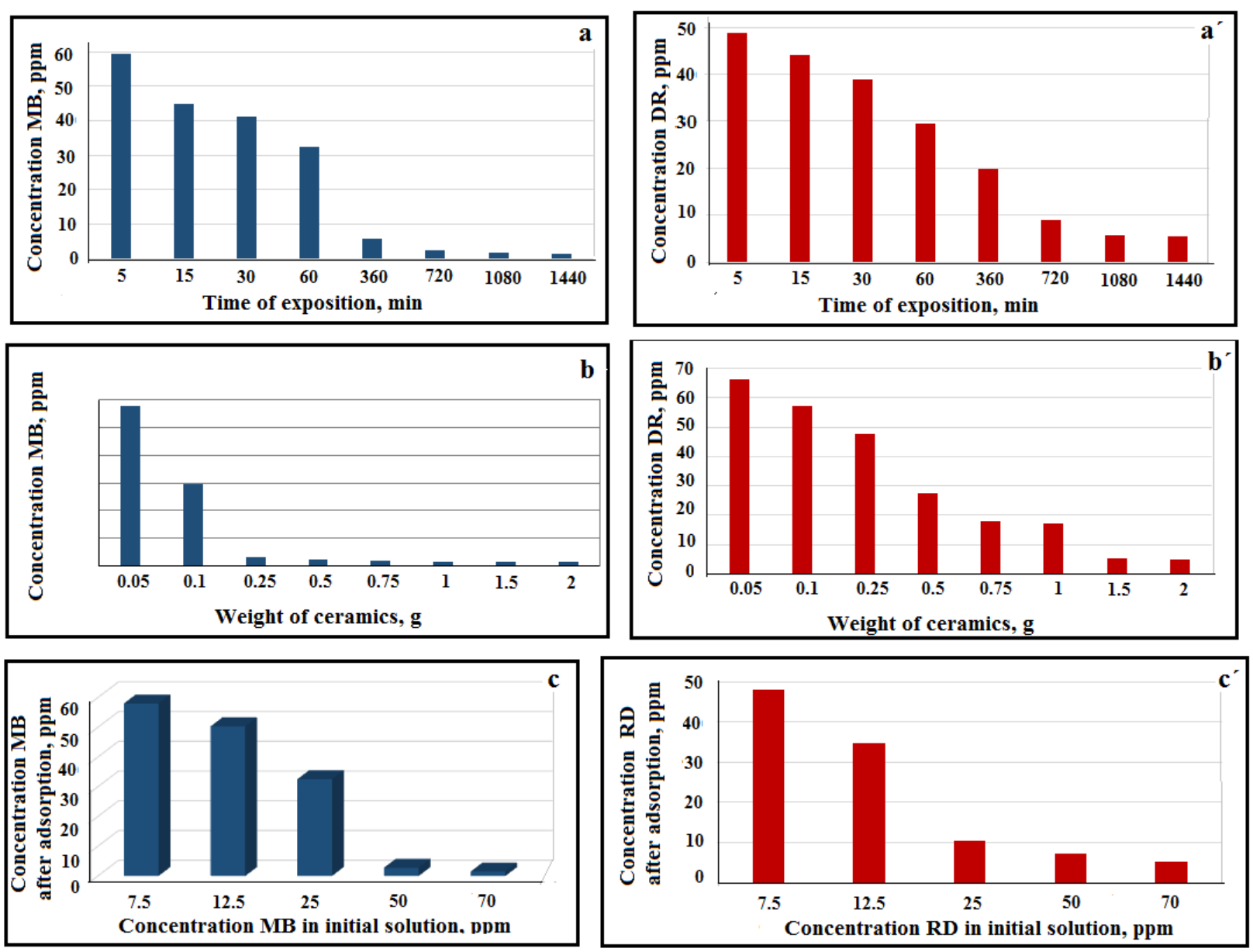

Fig. 9: Changing the intensity of UV-visible bands of absorption for MB (a - c) and RD (a - a') depending on time exposition (a, a'), weight of carbonized ceramics in solutions (b, b') and concentration dyes in solutions (c, $\left.c^{\prime}\right)$. For $(\mathrm{a}-\mathrm{c}) \lambda \sim 660 \mathrm{~nm}$. For $\left(\mathrm{a}^{\prime}-\mathrm{c}^{\prime}\right) \lambda \sim 508 \mathrm{~nm}$. All for ceramics with $\mathrm{T}_{\text {sint. }}=600{ }^{\circ} \mathrm{C}$, $\mathrm{t}_{\text {sint. }}=60 \mathrm{~min}$., and $\mathrm{T}_{\text {carbon. }}=600{ }^{\circ} \mathrm{C}, \mathrm{t}_{\text {carbon. }}=15 \mathrm{~min}$.

\section{CONCLUSIONS}

The obtained results showed that at thermo destruction of sucrose at $600^{\circ} \mathrm{C}$ during 15 min., within the pores of the ceramic body in conditions of oxygen deficiency is produced carbon material in the form of islets on the surface of pores and in the form of spherical particles of different sizes. In turn, carbon particles present a set of aggregates from chaotic graphene clusters. On surface of carbon particles is formed grapheme oxide. With increase of temperature and time of sucrose thermo destruction there is a complete burning of the resulting carbon. The temperature of ceramics sintering does not have a significant impact on the formation of the carbon material inside pores. Adsorption investigations show that the carbonized ceramics adsorbs dyes in good degree from water solution. Different type of dyes have the different velocity of adsorption.

\section{ACKNOWLEDGMENTS}

The authors wish to thanks Dr. G. Gonzalez-Rodriguez for the assistance at discussion of the results.

\section{REFERENCES}

[1] Salmang H. 1954. Die Physicalischen and Chemischen Grundlagen der Keramik, Dritte verbesserte Auflage, Berlin-Gottingen-Heidelberg.

[2] Budnikov P. P. 1964. The Technology of Ceramics and Refractories, The M.I.T. Press. Cambridge Mass.

[3] Vlasova, M., Parra Parra, A., Marquez Aguilar, P. A. and Kakazey, M. 2011. Purification of sewage by porous materials obtained with using different types of waste. J. Applied Sciences in Environmental Sanitation. 6 (2). P. 165179.

[4] Yakub I., Plappally A., Leftwich M., Malatesta K., Friedman K. C., Obwoya S., Nyongesa F., Maiga A. H., Soboyejo A.B.O., Logothetis S. and Soboyejo W. 2013. Porosity, Flow, and Filtration Characteristics of FrustumShaped Ceramic Water Filters. J. Environmental Engineering, 139 (7). P.987-994. 
[5] Sharmiwati M. S., Mizan R. M., and Noorhelinahani A. B. 2014. Preparation and characterization of ceramic sponge for water filter. Intern. J. Scientific and Technology Research. 3 (6). P. 103-106.

[6]Vlasova M., Rosales I., Kakazey M., Parra Parra A. and Guardian R. 2011. Formation of porous ceramics using cullet and biological waste of water purification. Sci. of Sintering. 43. P. 81-94.

[7] Simonis J. J. and Basson A. K. 2012. Manufacturing a low-cost ceramic micro porous filter and filter system for elimination of common pathogenic bacteria. Phys. Chem. Earth. 50-52. P. 269-276.

[8] Simonis J., Ndwandwe M., Basson A and Selepe T. 2014. Removal of selected microorganisms using silverimpregnated and coated, low-cost, micro-porous, ceramic water filters. J. Water, Sanitation and Hygiene for Development, 4 (1). P. $37-42$.

[9] Moreno-Castill C. and Pérez-Cadenas A. F. 2010. Carbon-Based Honeycomb Monoliths for Environmental GasPhase Applications. Materials. 3. P. 1203-1227.

[10] Avila P., Montes M. and Miró E.E. 2005. Monolithic reactors for environmental applications. A review on preparation technologies. Chem. Eng. J., 109. P. 11-36.

[11] Heck R. M., Gulati S.and Farrauto, R. J. 2001. The application of monoliths for gas phase catalytic reactions. Chem. Eng. J., 82. P.149-156

[12] Radovic L.R., Moreno-Castilla C. and Rivera-Utrilla J. 2001. Carbon materials as adsorbents in aqueous solutions. In Chemistry and Physics of Carbon; Radovic, L.R., Ed.; Marcel Dekker: New York, NY, USA, 27. P. 227406.

[13] Yates M., Martín J. A., Martín-Luengo M. A. and Blanco J. 2007. Study of the efficiency of monolithic activated carbon adsorption units. Stud. Surf. Sci. Catal., 160. P. 583-590.

[14] Studart A. R., Gonzenbach W.T., Tervoort E. and Gauckler L. J. 2006. Processing Routes to Macroporous Ceramics: A Review. J. Am. Ceram. Soc., 89 (6) P.1771-1789

[15] Colombo P. 2006. Conventional and Novel Processing Methods for Cellular Ceramics, Philos. Trans. Roy. Soc. A, 364. P.109-124.

[16] Rajamathi M., Thimmaiah S., Morgan P. E. D. and Seshadri R. 2001. Macroporous Materials from Crystalline Single-Source Precursors Through Decomposition Followed by Selective Leaching. J. Mater. Chem., 11 (10). P. 24892492 .

[17] Colombo P. and Hellmann J. R. 2002. Ceramic Foams from Preceramic Polymers. Mater. Res. Innovations, 6 (56). P. 260-72.

[18] Luyten J., Mullens S., Cooymans J., De Wilde A. M. and Thijs I. 2003. New Processing Techniques of Ceramic Foams. Adv. Eng. Mater., 5 (10). P. 715-8.

[19] Thijs I., Luyten J. and Mullens S.2004. Producing Ceramic Foams with Hollow Spheres. J. Am. Ceram. Soc., 87 (1). P. 170-2.

[20] Luyten J., Thijs I., Vandermeulen W., Mullens S., Wallaeys B. and Mortelmans R. 2005. Strong Ceramic Foams from Polyurethane Templates. Adv. Appl. Ceram., 104 (1) P. 4-8.

[21] Mizutani M., Takase H., Adachi N., Ota T., Daimon K. and Hikichi Y. 2005. Porous Ceramics Prepared by Mimicking Silicified Wood. Sci. Technol. Adv. Mater., 6 (1). P. 76-83.

[22] Kumar B. P., Kumar H. H. and Kharat D. K. 2005. Study on Pore-Forming Agents in Processing of Porous Piezoceramics. J. Mater. Sci.-Mater. Electronics, 16 (10). P. 681-686.

[23] Enríquez Méndez Y., Vlasova M., Kakazey M., Dominguez-Patiño M., Isaeva L. and Tomila T.2007. Low temperature synthesis of porous ceramics. Sci. Sintering, 39. P. 39-49.

[24] Enríquez Méndez Y. M., Vlasova M., Leon I., Trejo M. and Kakazey M. 2010. Properties of Low-Temperature Porous Ceramics on the Base of Clay-Fusible Glass Mixtures. J. Australian Ceramic Society, 46 (1). P. 53-62.

[25] Spudulis E. and Šavareika V. 2007. Peculiarities of Firing Porous Clay Products With Burning Out Additive. Materials Science (MEDŽIAGOTYRA), 13 (1). P. 61-64.

[26] Escardino A., García-Ten J., Feliu C. and Moreno A. 2010. Calcium carbonate thermal decomposition in whitebody wall tile during firing. I. Kinetic study. J. Eur. Ceram. Soc., 30 (10), P. 1989-2001.

[27] Boynton R.S. 1980. Chemistry and Technology of Lime and Limestone, 2nd edition. Wiley-Interscience, New York.

[28] Galwey A.K., and Laverty G. 1993. A kinetic and mechanistic study of the dehydroxylation of calcium hydroxide. Thermochimica Acta, 228. P. 359-378.

[29] Rodriguez-Navarro C., Ruiz-Agudo E., Luque A., Rodriguez-Navarro A. B. and Ortega-Huertas M. 2009. Thermal decomposition of calcite: Mechanisms of formation and textural evolution of $\mathrm{CaO}$ nanocrystals. American Mineralogist, 94. P. 578-593. 
[30] Burlak G., Vlasova M., Marquez Aguilar P.A., Kakazey M. and Xixitla-Cheron L. 2009. Optical percolation in ceramics assisted by porous clusters. Optics Communications, 282. P.2850-2856.

[31] Vlasova M., Kakazey M., Dominquez-Patiño M., Rodriguez Martinez A. and Ocampo G. 2009. Low Temperature Synthesis of Art Ceramics by Addition of Glass Powder. Silicate Industriels, 74 (7-8). P. 217-223.

[32] Froment G. M. and Hosten L. 1981. Catalytic kinetics: modeling, in Catalysis: Science and Technology, J. R. Anderson, and M. Boudart, Eds., 2, pp. 97-170. Berlin, Springler-Verlag.

[33] Data Base of FTIR-spectra http//:www.chem.uni-postdam.de/tools/index.html.

[34] Plusnina I.I. 1967. Infra-red spectra of silicate, Publishing house MSU, Moscow, 189 p.

[35] Sevilla M., Fuertes A.B. 2009. Chemical and structural properties of carbonaceous products obtained by hydrothermal carbonization of saccharides. Chemistry, 15(16). P. 4195-203.

[36] Deschanels X., Herault D., Arrachart G., Rey C., Grandjean A., Toquer G., Podor R., Zemb T., Cerveau G. and Corriu R. 2013. Comparison of two soft chemistry routes for the synthesis of mesoporous carbon/b-SiC nanocomposites. J Mater Sci., DOI 10.1007/s10853-013-7222-z.

[37] Zhongxin Chen, Ting Huang, Bo Cheng Jin, Jiantong Hu, Hongbin Lu and Steven Nutt. 2014. High yield synthesis of single-layer graphene microsheets with dimensional control. Carbon, 68. P. 167-174.

[38] Fang M., Wang K.G., Lu H.B., Yang Y.L. and Nutt S. 2010. Single-layer graphene nanosheets with controlled grafting of polymer chains, J. Mater. Chem. 20 , pp. 1982-1992.

[39] Zhao Y., Li W., Zhao X., Wang D. P. and Liu S. X. 2013. Carbon spheres obtained via citric acid catalysed hydrothermal carbonisation of cellulose. Materials Research Innovation, 17 (7). P. 546-551.

[40] Yufeng Tang, Fuqiang Huang, Wei Zhao, Zhanqiang Liu and Dongyun Wan. 2012. Synthesis of graphenesupported $\mathrm{Li}_{4} \mathrm{Ti}_{5} \mathrm{O}_{12}$ nanosheets for high rate battery application, J. Mater. Chem., 22. P. 11257-11260.

[41] Shubhda Srivastava, Kiran Jain, Singh V. N., Sukhvir Singh, Vijayan N., Nita Dilawar, Govind Gupta and Senguttuvan T. D. 2012. Faster response of $\mathrm{NO}_{2}$ sensing in graphene- $\mathrm{WO}_{3}$ nanocomposites, Nanotechnology, 23 (20). P. 205501-205508.

[42] Dissanayake K. T., Rohini de Silva W., Kumarasinghe A., and Nalin de Silva K.M. 2014. Synthesis of graphene and graphene oxide based nanocomposites and their characterization. SAITM Research Symposium on Engineering Advancements (SAITM - RSEA 2014). P. 75-78.

[43] Bustos-Ramires K., Martinez-Ernandez A. L, Martinez-Barrera G., de leaza M., Castaño V. M., and VelascoSantos C. 2013. Covalently Bonded Chitosan on Craphene Oxide via Redox Reaction. Materials, 6. P. 911-920.

[44] Shaw Yong Toh, Kee Shyuan Loh, Siti Kartom Kamarudin, Wan Ramli and Wan Daud. 2014. Graphene production via electrochemical reduction of graphene oxide: Synthesis and characterization. Chemical Engineering Journal, 235. P. 422-434.

[45] Berezkin V. I. 2000. Fullerenes as nucleus of soot particles. Solid State Physics,42 (3). P.580-585.

[46] Donnet J.B. 1982. Structure and reactivity of carbons: from carbon black to carbon composites. Carbon, 20 (1). P.267-282.

\section{AUTHOR's BIOGRAPHY}

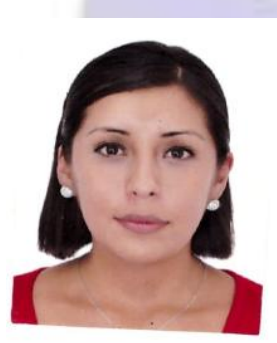

Catalina BustosRivera Bahena obtained master's degree in Engineering and Science Application in $2011 \mathrm{y}$. in Autonomy University of State Morelos, ClICAp, with speciality Technology of Materials. At present continues education at ClICAp for obtaining the degree of Ph.D. on the same speciality. The main scientific interest lay in the region of environmental conservation

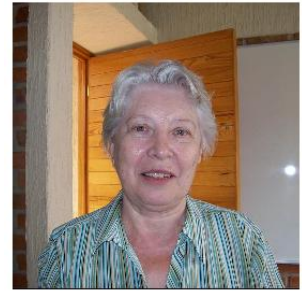

Marina Vlasova received the Ph. D. degree in $1967 \mathrm{y}$. with a speciality "Solid state physics". In 1996 y. received Dr. Sci. degree with a speciality "Chemical sciencies". The major research interests lie in the region of synthesis of oxide and oxygen-free powders, their sintering, phase formation and study the properties of ceramic materials. She is Research Professor in Autonomy University of State Morelos, CIICAp, directs the Laboratory of Advanced ceramics. 


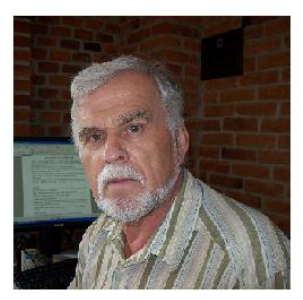

Mykola Kakazey received the Ph. D. degree in 1969 y. with a speciality "Solid state physics". In 1991 y. received Dr. Sci. degree with a specialty "Physics of semiconductors and dielectrics". The major research interests lie in the region of evolution defects structure of dispersive structures during different types of technology processing's. He is Research Professor in Autonomy University of State Morelos, CIICAp,

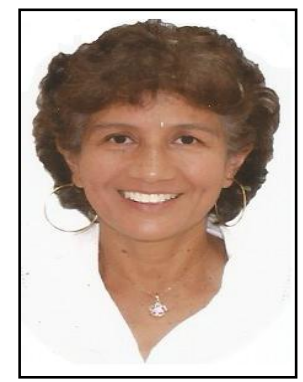

Gloria Francisca Dominguez Patiño obtained the Ph. D. degree in 2002 y. with a speciality "Materials Science and Engineering". The major research interests lie in the region of investigation of adsorbtion processes, purification of wastewater from dyes of textile industry, study of the properties of plant extracts as corrosion.

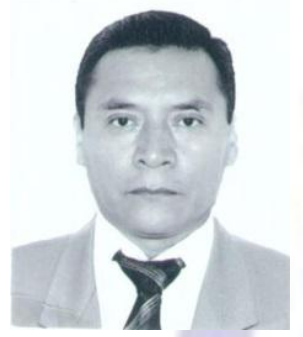

Rene Guardián Tapia obtained the Ph. D degree in 2010, with a specialty "Materials Science and Engineering". His main research lines include chemical and microstructural characterization, investigation of mechanical properties of advanced materials such as composites, biomaterials and nanostructured materials. 